\title{
A non-native amphipod consumes eelgrass inflorescences in San Francisco Bay
}

\author{
Laura K. Reynolds ${ }^{1,2, *}$, Lindsey A. Carr ${ }^{1,3}$, Katharyn E. Boyer ${ }^{1}$ \\ ${ }^{1}$ Romberg Tiburon Center for Environmental Studies and Department of Biology, San Francisco State University, Tiburon, \\ California 94920, USA \\ ${ }^{2}$ Present address : Department of Environmental Sciences, University of Virginia, Charlottesville, Virginia 22904, USA \\ ${ }^{3}$ Present address: Department of Biology, University of North Carolina, Chapel Hill, North Carolina 27599, USA
}

\begin{abstract}
Intense herbivory can alter habitat characteristics, and grazing on reproductive structures can reduce plant fitness and long-term population stability. Herbivory on seagrasses is often limited to epiphytes; however, direct grazing has been observed recently in several systems. In San Francisco Bay, California, we documented extensive damage to leaves and especially inflorescences of eelgrass Zostera marina concurrent with blooms of the non-native amphipod Ampithoe valida. Field surveys found peaks of $A$. valida abundance when eelgrass was flowering, and greater abundance on flowering than vegetative shoots, with particularly high abundances on reproductive structures (spathes) in late developmental stages (with ripe fruits or post seed release). Laboratory experiments showed that $A$. valida consumed leaf and spathe tissue (as well as whole fruits), but usually preferred spathes to leaves. Spathes are structurally complex and likely provide better habitat, increasing opportunity for consumption. Low field algal abundances do not fully explain eelgrass herbivory, as amphipods grazed eelgrass substantially even when offered algae. When presented with eelgrass from both the amphipod's native (Virginia) and invaded range (California), the latter was consumed at significantly higher rates. Neither nutrient nor phenolic content adequately explain the tissue preference. Greater size of California eelgrass may have promoted incidental feeding on spathes used as habitat, but does not explain a California bias during consumption of structurally simple leaves. Field densities and laboratory consumption rates suggest that this non-native amphipod could remove all seeds in a California eelgrass meadow in 1-3 wk, thus challenging maintenance of genetic diversity and long-term meadow persistence.
\end{abstract}

KEY WORDS: Seagrass $\cdot$ Zostera marina $\cdot$ Ampithoe valida $\cdot$ Herbivory $\cdot$ Seed predation

\section{INTRODUCTION}

Herbivory can influence terrestrial and aquatic ecosystems by altering abundance, distribution, or fitness of plants (Lubchenco \& Gaines 1981, Fritz \& Simms 1992, Schmitz 2008). In Amazonian forests, tree species composition varies along a soil gradient due to insect grazers specific to sandy soils preferentially consuming the better competitor (Fine et al. 2004). Direct consumption of reproductive tissues (flowers, fruits, seeds) can have consequences, such as decreased pollen production in male flowers or reduced pollinator visits to female flowers, which diminish sexual reproductive success (Mutikainen \& Delph 1996, Leavitt \& Robertson 2006). Leaf damage by an herbivorous caterpillar to wild radish reduces the flower size and thus pollinator visits, resulting in similar impacts of decreased plant fitness (Lehtilä \& Strauss 1997).

Impacts of herbivory become more pronounced when consumption rates rise dramatically, usually 
due to an increase in herbivores (e.g. Edmunds \& Carpenter 2001, Mumby et al. 2006). Such changes can result from loss of herbivore predators, e.g. a decline in sea otters allowed urchins to increase in density and graze down kelp forests in the US Pacific Northwest, removing the physical habitat used by many other species (Estes \& Duggins 1995). Introductions of new grazers to a system can also result in increased rates of herbivory (e.g. Wardle et al. 2001, Donlan et al. 2002). For example, the invasion of the golden apple snail Pomacea canaliculata into Thailand wetlands resulted in a reduction of aquatic plant biomass and an increase in water column nutrients, leading to large phytoplankton blooms (Carlsson et al. 2004).

Seagrasses are submerged angiosperms that provide habitat for many species in shallow waters worldwide (Green \& Short 2003, Short et al. 2011). Historically, seagrasses were subjected to significant grazing by large mammals and reptiles, but these grazers are now functionally extinct in most systems (Jackson et al. 2001). In modern seagrass ecosystems, herbivores benefit seagrasses by predominantly consuming epiphytic algae, which compete with the plant for light and nutrients (Hughes et al. 2004). However, there is a growing body of literature suggesting that the importance of direct consumption of seagrasses is underappreciated (see Heck \& Valentine 2006). For example, the purple urchin Lytechinus variegates, above a critical density, is capable of consuming $>50 \%$ of the aboveground biomass of turtlegrass Thalassia testudinum along the U.S. Gulf Coast, leading to local extinction of the plant (Valentine \& Heck 1999). Preferential grazing on Halodule wrightii by reef fish results in dominance of the slower growing, more herbivore-resistant Thalassia testudimum adjacent to south Florida coral reefs (Armitage \& Fourqurean 2006). Herbivory by small mesograzers, such as isopods, in large densities can also impact seagrass productivity and survival (Nienhuis \& Groenendijk 1986, Brearley \& Walker 1995). Likewise, herbivory by a small commensal limpet on eelgrass in southern California can shift plant limitation from light to carbon and cause catastrophic plant die-back (Zimmerman et al. 1996). When seagrasses are directly grazed, herbivores can alter seagrass demography by preferential consumption of young tissue (Heck \& Valentine 2006), by increasing production of new shoots (Zieman et al. 1984, Valentine et al. 1997), and by stimulating flowering and seed production (Peterken \& Conacher 1997).

In tropical and temperate seagrass meadows, herbivory on sexual reproductive tissue has been docu- mented and may reduce seed production, seedling recruitment, and survivorship, altering meadow structure and stability. The tanaid Zeuxo sp. consumes up to $30 \%$ of Zostera marina seeds in Otsuchi Bay, Japan (Nakaoka 2002), and in the Mediterranean Sea the urchin Paracentrotus lividus preferentially consumes flowering structures of Posidonia oceanica over vegetative shoots (Vergés et al. 2007). Crabs and isopods consume inflorescences and seeds of surfgrass Phyllospadix torreyi, removing up to $50 \%$ of seeds in Southern California (Holbrook et al. 2000). In North Sea $Z$. marina meadows, many invertebrates (Platyhelminthes, Nematoda, Copepoda, and Polychaeta) live primarily on flowering shoots and may use them as food (Hellwig-Armonies 1988). Further, crustacean, mollusc, and fish species have been shown to eat eelgrass seeds from the sediment surface (Wigand \& Churchill 1988, Fishman \& Orth 1996, Orth et al. 2002). Removing a large number of seeds can have a catastrophic impact on annual seagrass meadows, which require seeds to recolonize yearly. Seed removal can also impact perennial meadows by reducing genetic diversity. Seagrasses reproduce both asexually by cloning and sexually by flowering, but only sexual reproduction enhances genetic diversity (Hemminga \& Duarte 2000). Genetic variation in seagrasses equates to higher fitness (Williams 2001, Hämmerli \& Reusch 2003) and disturbance resistance (Hughes \& Stachowicz 2004, Reusch et al. 2005).

Decreases in seagrass stability and fitness due to seed removal or loss of genetic diversity are of concern since anthropogenic impacts are causing large seagrass declines worldwide (Short \& WyllieEcheverria 1996, Orth et al. 2006, Waycott et al. 2009). Seagrasses provide many ecosystem services: sediment and nutrient filtration, sediment stabilization, and nursery and resident habitat for ecologically and economically important species (Hemminga \& Duarte 2000). Understanding the role of herbivory in these systems is essential to effective conservation.

We have observed extensive damage to several Zostera marina meadows in San Francisco Bay, California, USA, concomitant with high densities of the introduced amphipod Ampithoe valida. This tube building amphipod, native to the US Atlantic coast (Bousfield 1973), was first recorded in San Francisco Bay in 1941 (Cohen \& Carlton 1995) and is now found from Newport Bay, California, to Puget Sound, Washington (Cohen \& Carlton 1995). In its native range, it consumes algae; a preference for Ulva sp. was documented in Massachusetts (Nicotri 1980) and 
Gracilaria sp. in North Carolina (Duffy \& Hay 1994). Many mesograzers in seagrass meadows are also known to preferentially consume epiphytic algae (Valentine \& Duffy 2006). No studies to date have documented $A$. valida direct consumption of seagrass tissues.

Our field observations suggest that Ampithoe valida in its introduced range of San Francisco Bay not only consumes large quantities of Zostera marina, but may prefer inflorescences to leaves. We used microcosm experiments to test the hypotheses that A. valida preferentially consumes: (1) eelgrass inflorescences over leaves and (2) maturing inflorescences (with well-developed fruits) over those in early stages of floral development. Our observation of direct eelgrass grazing, in apparent contradiction to $A$. valida feeding habits in its native range (on algae) (Nicotri 1980, Duffy \& Hay 1994), could be due to low algal abundances in San Francisco Bay (Carr et al. 2011, G. Santos \& K. Boyer unpubl. data) limiting food choices. Therefore, we also hypothesized that (3) little to no eelgrass tissue is consumed when algal food choices are available (thus eelgrass consumption in the field is by default). We also considered that (4) San Francisco Bay eelgrass could be more desirable (e.g. more palatable or less defended against herbivory) to introduced $A$. valida than eelgrass from its native range, thus explaining observed differences in feeding patterns. In addition to microcosm experiments testing these hypotheses, we quantified A. valida abundances and feeding damage in the field as a first step in evaluating the potential impacts of $A$. valida herbivory on the maintenance of $Z$. marina meadows.

\section{MATERIALS AND METHODS}

A field survey was conducted in the Zostera marina meadow at Robert Crown Memorial State Beach

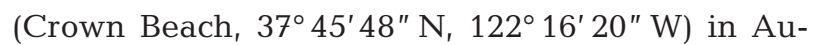
gust of 2006. Crown Beach is a large, monospecific, mostly annual seagrass meadow located in the central-eastern portion of San Francisco Bay. Vegetative and flowering shoot density were quantified in ten $0.25 \mathrm{~m}^{2}$ quadrats along a $100 \mathrm{~m}$ transect. Additionally, 20 vegetative and 20 flowering shoots were haphazardly chosen, carefully collected, and quickly placed in individual bags to keep associated epifauna communities intact. The number of spathes (leaf-like bracts with enclosed flowers or fruits) on each flowering shoot and the number of fruits in each spathe were counted in order to estimate seed pro- duction. In addition, the number of Ampithoe valida on each shoot was counted. Overall amphipod density was estimated as the product of number of amphipods per shoot and shoot density scaled for vegetative and flowering field densities. Quarterly during the 2007 growing season, Z. marina and A. valida density measurements were repeated. ANOVA was used to compare densities on vegetative and flowering shoots on each date, and the relationship between vegetation density and amphipod density was explored with Pearson correlation analysis. In addition, in August 2007, 20 vegetative and 20 flowering shoots were returned to the laboratory, and the number of marks consistent with A. valida herbivory was counted.

Because we found higher numbers of amphipods on flowering shoots than vegetative shoots, we examined where on the flowering shoot the amphipods lived. In July 2009 we haphazardly chose and carefully collected individual spathes in all available stages of development (De Cock 1980) from flowering shoots, as well as young vegetative leaves of similar length, placed them in individual bottles, and returned them to the lab. Samples were collected from a large perennial meadow near Point San Pablo $\left(37^{\circ} 58^{\prime} 28^{\prime \prime} \mathrm{N}, 122^{\circ} 24^{\prime} 50^{\prime \prime} \mathrm{W}\right)$ in northeast San Francisco Bay. The number of Ampithoe valida was counted on each spathe or leaf. Amphipod abundance on different tissues was compared using ANOVA, followed by post-hoc comparisons using Tukey's tests. For each of these tissues, carbon and nitrogen content were determined by mass spectrometry at the University of California-Davis Isotope Facility, and differences were analyzed using ANOVA, followed by post-hoc comparisons using Tukey's tests.

Ampithoe valida food preference was assessed with laboratory experiments. In each of 4 microcosm experiments, small plastic containers $(9 \mathrm{~cm}$ diameter, $250 \mathrm{ml}$ volume) were filled with $0.75 \mathrm{~cm}$ of sand. Preweighed portions of plant tissue were added. All tissues were of similar size to control for differences in encounter rates (with seeds being the exception and having a smaller area), but because tissues had different densities, initial masses varied. Tissue was floating in the water column or resting on the sand depending on the natural buoyancy. Each container was randomly assigned as +amphipod (50 individuals) or control (no amphipods added). The number of amphipods added was conservatively low relative to peak field densities. Plant tissues and amphipods were collected from the same field site in a given experiment (Crown Beach in Expts 1 and 2, Point San Pablo in Expt 3, and Bay Farm Island in the bicoastal 
experiment). Containers were covered with nylon mesh and held in flowing bay water for 5 to $10 \mathrm{~d}$, after which tissue was removed, blotted dry, and reweighed. Tissue was monitored during the experiment, and all experiments were broken down before amphipods consumed all of one food choice and before significant natural decomposition occurred in the control containers. None of the tissues in the control containers changed significantly in mass, and because incorporating these kinds of controls can non-rigorously suppress variance (Roa 1992, Manly 1993), we did not use those controls in our calculations. For each replicate, we calculated the total consumption (mass lost for all tissues) and assigned a proportional consumption to each food choice. Differences in the proportional loss were analyzed using Hotelling's mulitivariate $\left(\mathrm{T}^{2}\right)$ as described by Lockwood (1998). Rates of consumption for each food choice were calculated as mass lost per individual amphipod per day. Because the mass loss in stage 4 spathes could be due to consumption of fruits or simply seed release, we used ANOVA to compare the number of fruits and seeds in the spathes and on the sediment in control versus experimental containers. An average seed mass was used to estimate the proportion of total stage 4 consumption that can be attributed to consumption of fruits.

The time of year, number or replicates included, and food choices provided for each of the 4 experiments is summarized in Table 1. The maturity (developmental stage) of flowers was determined according to De Cock (1980) and is described briefly in
Table 1. Seeds were counted as opposed to weighed because their small mass made differences difficult to detect using available equipment. Counts were converted to mass using a mean seed mass calculated by weighing 10 independent groups of 20 seeds. Because loss of biomass in stage 4 spathes could be due to consumption of fruits or to the dropping of seeds from the spathes, in all experiments that included stage 4 spathes, seeds remaining in the spathe and on the sediment at the conclusion of the experiment were counted. Counts were converted to mass as above. In addition to various seagrass structures, algae were included as food choices. The red alga Gracilaria sp., the green alga Ulva sp., and epiphytic algae have all been reported as dominant food sources for these amphipods in their native habitats (Nicotri 1980, Duffy \& Hay 1994); therefore, they were included to provide alternate food choices to eelgrass tissues.

Because we observed high rates of eelgrass consumption by Ampithoe valida in invaded San Francisco Bay despite little evidence of direct consumption in native habitats (Douglass et al. 2011), the fourth food choice experiment offered plants from both native and non-native habitats. Vegetative and flowering shoots were collected from Bay Farm Island

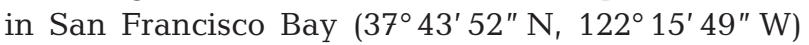
and from South Bay, Virginia (VA), USA (37 $15^{\prime} 45^{\prime \prime} \mathrm{N}$, $75^{\circ} 48^{\prime} 46^{\prime \prime}$ W) in May 2010. Both are large perennial meadows. Plants from VA were shipped overnight to San Francisco State University's Romberg Tiburon Center for Environmental Studies. Plants were

Table 1. Experimental set-up and results. In each experiment, different parts of the seagrass Zostera marina as well as listed algae were presented in equal amounts to 50 individuals of non-native amphipods Ampithoe valida. Developmental stages of flowering spathes were determined according to De Cock (1980). Feeding rates (values in []) were calculated from mass change in control and amphipod treatments and are presented as mg consumed ind.$^{-1} \mathrm{~d}^{-1}$. veg $=$ vegetative. CA $=$ California.

$\mathrm{VA}=$ Virginia. Spathe stages: $0-1=$ very early floral development; $4=$ with well developed fruits; $6=$ seeds released

\begin{tabular}{|c|c|c|c|}
\hline $\begin{array}{c}\text { Expt } 1 \\
\text { October } 2006 \\
n=10\end{array}$ & $\begin{array}{c}\text { Expt } 2 \\
\text { September } 2007 \\
n=8\end{array}$ & $\begin{array}{c}\text { Expt } 3 \\
\text { April } 2009 \\
n=5\end{array}$ & $\begin{array}{c}\text { Bicoastal Expt } \\
\text { May } 2010 \\
\text { n }=8\end{array}$ \\
\hline $\begin{array}{l}\text { Leaves: young, veg, } \\
{[0.07]}\end{array}$ & $\begin{array}{c}\text { Leaves: young, veg, } \\
{[0.1]}\end{array}$ & $\begin{array}{c}\text { Leaves: young, veg, } \\
{[0.2]}\end{array}$ & $\begin{array}{l}\text { Leaves: young, veg } \\
\text { from CA, [0.3] }\end{array}$ \\
\hline $\begin{array}{c}\text { Spathes: stage } 0-1 \text {, } \\
{[0.1]}\end{array}$ & $\begin{array}{c}\text { Spathes: stage } 0-1, \\
{[0.005]}\end{array}$ & $\begin{array}{c}\text { Leaves: old, veg, } \\
\text { with epiphytes } \\
\text { removed, [0.1] }\end{array}$ & $\begin{array}{l}\text { Leaves: young, veg } \\
\text { from VA, [0.03] }\end{array}$ \\
\hline $\begin{array}{c}\text { Spathes: stage } 4, \\
{[0.3]}\end{array}$ & $\begin{array}{c}\text { Spathes: stage } 4, \\
{[0.7]}\end{array}$ & $\begin{array}{l}\text { Leaves: old, veg, } \\
\text { with epiphytes intact, [1.0] }\end{array}$ & $\begin{array}{c}\text { Spathes: stage } 4, \\
{[0.5]}\end{array}$ \\
\hline $\begin{array}{c}\text { Spathes: stage } 6, \\
{[0.3]}\end{array}$ & $\begin{array}{c}\text { Algae: Gracilaria sp., } \\
{[0.6]}\end{array}$ & $\begin{array}{c}\text { Algae: Gracilaria sp., } \\
{[0.3]}\end{array}$ & $\begin{array}{c}\text { Spathes: stage } 4, \\
{[0.002]}\end{array}$ \\
\hline Seeds, [0.0001] & $\begin{array}{l}\text { Seeds not offered but consumed } \\
\text { from late-stage spathes [0.2] }\end{array}$ & Algae: Ulva sp., [0.5] & $\begin{array}{l}\text { Algae: Gracilaria sp. } \\
\text { from CA, [1.8] }\end{array}$ \\
\hline
\end{tabular}


shipped cold and wrapped in towels moistened with seawater. A feeding experiment similar to our previous experiments started the next day which included Zostera marina vegetative leaves and stage 4 spathes originating from both CA and VA, with Gracilaria sp. collected from CA serving as an alternate food choice. VA and CA Z. marina tissues were distinguished during the experiment by size, as the former were about half the length and width and had much smaller fruits and seeds. Because of this size difference, 2 pieces of vegetative leaf and 2 spathes from flowering shoots were used from VA, while only one portion of each tissue from CA was used. Amphipods (from San Francisco Bay) were added at the same densities as in the other food choice experiments described above, and feeding preference was analyzed as above. Plants from this experiment were analyzed for carbon and nitrogen content using a Carlo Erba Elemental Analyzer. Total phenolic concentrations were estimated using the modified FolinCiocalteu assay (Bolser et al. 1998) on oven-dried tissue. Tissues were from different plants and completely independent. Differences in tissue nutrient content and phenolic content were analyzed using ANOVA, followed by post-hoc comparisons using Tukey's tests. The lengths of flowering and vegetative shoots, widths of leaves or spathes, and lengths and widths of seeds from each source were measured and differences evaluated with ANOVA.

\section{RESULTS}

Results from a survey conducted in 2006 demonstrated that potential seed density based on fruit counts at Crown Beach was $\sim 250$ seeds $\mathrm{m}^{-2}$. During the 2007 growing season, Ampithoe valida density showed significant seasonality, and there was a relationship between flowering shoot density and amphipod density $\left(\mathrm{R}^{2}=0.73, \mathrm{p}=0.1\right)$. When flowering shoots were present, amphipod density was greater on them than on vegetative shoots (shoot morphology: $F=30.0, \mathrm{p}<0.0001$, date: $F=14.8, \mathrm{p}<0.0001$, and date $\times$ shoot morphology: $F=10.16, \mathrm{p}=0.002$ ). Across the 2 sampling years, plant density and amphipod preference for flowering shoots as habitat remained consistent; however, amphipod density was much greater during the 2006 sampling (Fig. 1).

Examination of amphipod distribution on flowering shoots in 2009 demonstrated that amphipods are distributed unevenly over spathes of different developmental stages $(F=5.69, \mathrm{p}=0.002)$. There was no difference in amphipod density between vegetative and early developmental flowering spathes (stage $0, \mathrm{p}=$ $0.97)$. Likewise, there was no difference between flowering spathes in the later stages (4 and 6) of development $(p=0.99)$; however, there were significantly more amphipods on these late stage spathes than vegetative leaves or early stage spathes (vegetative vs. stage 4 , stage $6: \mathrm{p}=0.02,0.01$; stage 0 vs. stage 4 , stage 6: $\mathrm{p}=0.05,0.04$ ) (Fig. 2).

$\mathrm{C}, \mathrm{N}$, and $\mathrm{C}: \mathrm{N}$ varied significantly among tissues (C: $F=34.52, \mathrm{p}<0.0001 ; \mathrm{N}: F=18.46, \mathrm{p}<0.0001$; $\mathrm{C}: \mathrm{N}: F=18.38, \mathrm{p}<0.0001)$. C:N generally increased from vegetative leaves to young inflorescences to older inflorescences to seeds, with the exception that the oldest inflorescences (stage 6) had a slightly lower C:N (Fig. 2). $\mathrm{N}$ was highest in vegetative leaves and immature spathes (stages 0 to 1 ), and lowest in late stage spathes (stages 4 and 6). Even though seeds had a significantly higher $\mathrm{N}$ content than either stage 4 or stage 6 spathes, stage 6 spathes (which by definition have lost their seeds) had a significantly lower $\mathrm{N}$ content than stage 4 spathes with developing seeds present. C content was lowest in the stage 6 spathes where seeds had been released and tissues were decaying. Seeds had the highest C content (Fig. 2).
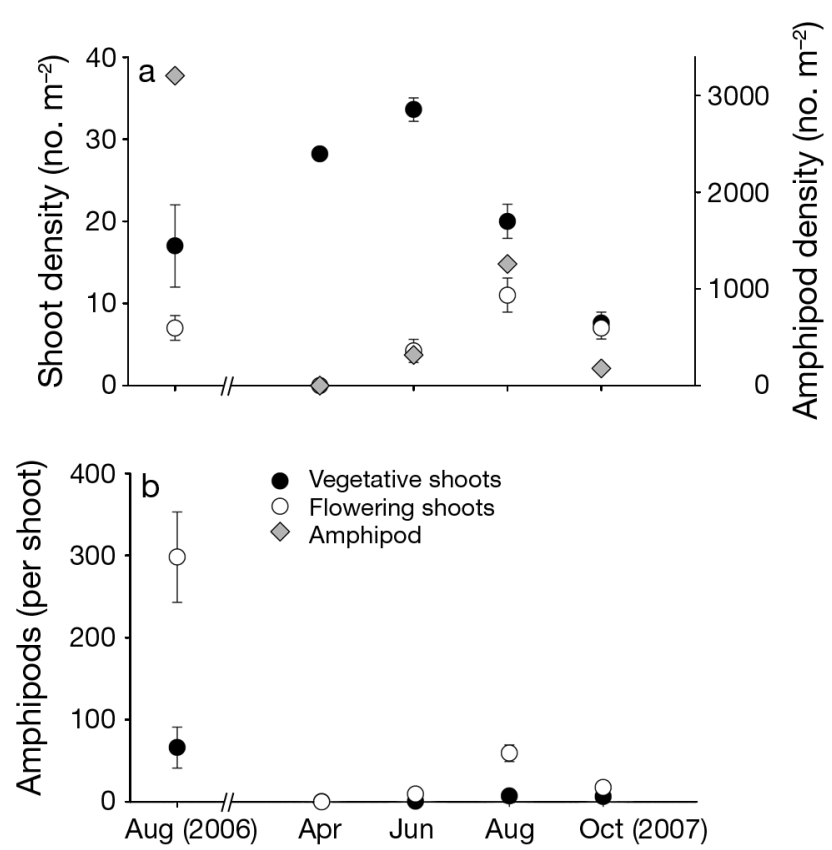

Fig. 1. (a) Density of vegetative and flowering Zostera marina shoots and Ampithoe valida in 2006 and 2007 at Robert Crown Memorial State Beach in San Francisco Bay. (b) Number of $A$. valida per vegetative or flowering shoot over time. Means $\pm 1 \mathrm{SE}$. There are no error bars for amphipod density as those are a product of shoot density and amphipod density per shoot. Other error bars are sometimes too small to be visible 


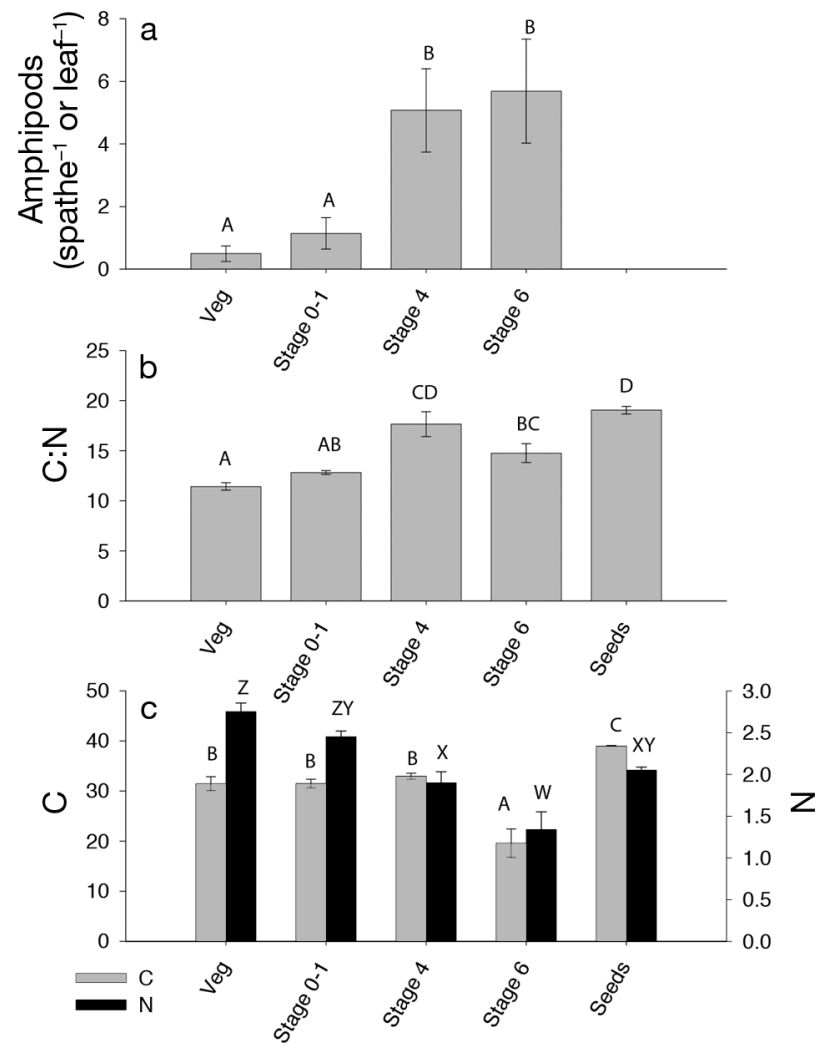

Fig. 2. (a) Number of Ampithoe valida on Zostera marina vegetative leaves (veg) or flowering spathes at different developmental stages $(0-1 ; 4 ; 6)$. (b) Carbon to nitrogen ratios for each $Z$. marina tissue type. (c) Carbon and nitrogen concentrations (\% dry mass) for each $Z$. marina tissue type. Means \pm 1 SE. Different letters indicate significant differences according to post-hoc Tukey's tests

Just before peak flowering in September 2007, $15 \%$ of vegetative shoots and $85 \%$ of flowering shoots showed signs of damage by amphipod herbivory. Damage on vegetative shoots was limited to younger leaves. A total of $99 \%$ of stage 4 spathes showed some damage.

In feeding Expt 1, control tissues lost little mass (mean ratio of initial to final mass $=0.8$ ). All experimental tissues, except for loose seeds, showed signs of herbivory when amphipods were present, but foods were not consumed in the same proportions $\left(\mathrm{T}^{2}=39,000, F=5329, \mathrm{df}=4,5, \mathrm{p}<0.0001\right)$. Amphipods consumed stage 4 and 6 spathes significantly more than stage 1 spathes, vegetative leaves, or loose seeds on the sediment surface (Fig. 3). Ampithoe valida consumed vegetative leaves, stage 1 spathes, stage 4 spathes, stage 6 spathes, and seeds on the sediment at rates of $0.07,0.1,0.3,0.3$, and $0.0001 \mathrm{mg}$ ind. ${ }^{-1} \mathrm{~d}^{-1}$, respectively. Visual inspection showed that some mature fruits or seeds were lost from stage 4 spathes. At the end of the experiment, there were fewer fruits remaining in the spathes $(-5.2)$ in amphipod treatments $(F=52.45, \mathrm{p}<0.0001)$; however, numbers of seeds on the sediment were similar between treatments. Using the average fruit mass of $5.8 \mathrm{mg}$, the mature fruit or potential seed consumption rate from the spathes was $0.09 \mathrm{mg}$ ind. ${ }^{-1} \mathrm{~d}^{-1}$, or $30 \%$ of the total stage 4 spathe consumption.

The results from feeding Expt 2 paralleled those of Expt 1. Control tissue varied little, with an initial to final biomass ratio of 0.9 . There was a significant difference in amphipod consumption among the food choices $\left(\mathrm{T}^{2}=108, F=26.99\right.$, $\left.\mathrm{df}=3,6, \mathrm{p}=0.0007\right)$. Amphipods consumed more mature seagrass spathes (stage 4) and red macroaglae (Gracilaria sp.) than vegetative leaves or immature spathes (stage 0) (Fig. 3). Ampithoe valida consumed vegetative leaves, stage 1 spathes, stage 4 spathes, and macroalgae at rates of $0.1,0.005,0.7$, and $0.6 \mathrm{mg}$ ind. ${ }^{-1} \mathrm{~d}^{-1}$, respectively (Table 1). At the end of the experiment, there were fewer fruits remaining in the stage 4 spathes in the experimental containers than in the controls $(-5.6)(F=19.55, \mathrm{p}=0.0007)$ and a similar number of seeds in the sediment when amphipods were present. Assuming that the difference in fruit loss between controls and amphipod treatments was due to herbivory, A. valida consumed mature fruits or seeds at a rate of $0.2 \mathrm{mg}$ ind. ${ }^{-1} \mathrm{~d}^{-1}$, making fruit or seed consumption $\sim 30 \%$ of the total stage 4 spathe consumption.

In feeding Expt 3, biomass in control treatments again did not change dramatically, with an average initial to final biomass ratio of 0.9 . There was a significant difference in amphipod consumption among the food choices $\left(\mathrm{T}^{2}=130000, F=8840, \mathrm{df}=4,1, \mathrm{p}=\right.$ 0.008). This experiment was conducted in April, before eelgrass flowering shoots were abundant. During that time, amphipods consumed epiphytized leaves significantly more than any other food choice. Ampithoe valida consumed young leaves, old leaves, and epiphytized leaves at rates of $0.2,0.1$, and $1.0 \mathrm{mg}$ ind..$^{-1} \mathrm{~d}^{-1}$, respectively, and Gracilaria sp. and Ulva sp. at rates of 0.3 and $0.5 \mathrm{mg}$ ind. ${ }^{-1} \mathrm{~d}^{-1}$, respectively.

The bicoastal feeding experiment also showed differences in food preference $\left(\mathrm{T}^{2}=1700, F=242, \mathrm{df}=\right.$ $4,4, \mathrm{p}<0.0001)$. Plant tissue originating from CA was consumed at much higher rates than tissue originating from VA, and the red macroalga was consumed at the highest rate. Using previous assumptions, Ampithoe valida consumed leaves originating from VA and CA at rates of 0.03 and $0.3 \mathrm{mg}$ ind. ${ }^{-1} \mathrm{~d}^{-1}$, respectively, stage 4 spathes from VA and CA at rates 


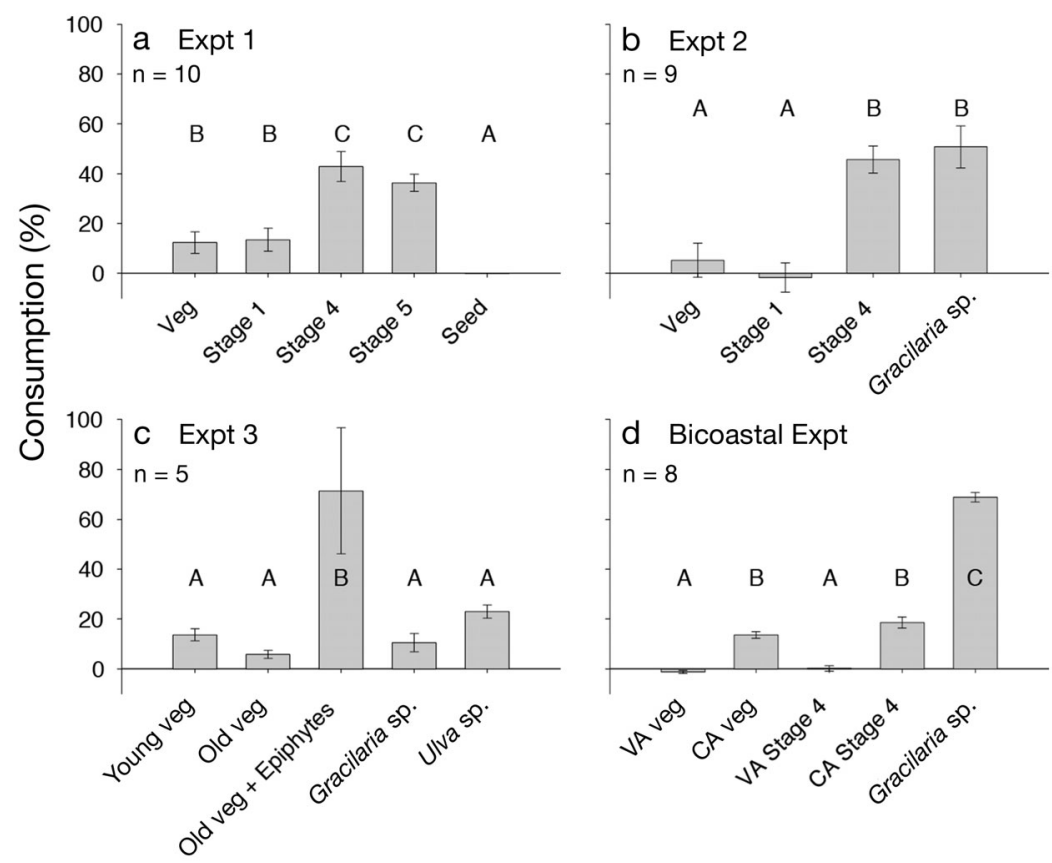

Fig. 3. Proportional consumption of tissues incubated with Ampithoe valida. Means \pm 1 SE. veg = leaf from vegetative shoot; 1 , 4, or $6=$ developmental stage of spathe from flowering shoot according to De Cock (1980). CA = California, VA = Virginia. Bars that do not share a letter are significantly different when analyzed with Hotelling's multivariate $\left(\mathrm{T}^{2}\right)$

of 0.002 and $0.5 \mathrm{mg}$ ind. ${ }^{-1} \mathrm{~d}^{-1}$, and Gracilaria sp. at a rate of $1.8 \mathrm{mg}$ ind. ${ }^{-1} \mathrm{~d}^{-1}$. The spathes from VA lost fruits; however, most were found on the sediment as seeds at the end of the experiment. CA spathes were slightly less developed and did not release many seeds during the experiment. Those seeds that were lost from CA spathes were not found on the sediment at the conclusion of the experiment and were presumably consumed. There was no effect of amphipod presence on seed recovery for the VA tissue $(F=0.66$, $\mathrm{p}=0.4)$; however, fewer CA seeds were recovered when amphipods were present $(F=4.5, \mathrm{p}=0.05)$.

Tissues used in the bicoastal feeding experiment varied in concentrations of both $\mathrm{C}(F=86.82, \mathrm{p}<$ $0.0001)$ and $N(F=82.99, \mathrm{p}<0.0001)$. Seeds and spathes had higher C content than leaves (Fig. 4). Only leaf $\mathrm{C}$ varied by source; leaves from CA had significantly higher $\mathrm{C}$ than those from VA. All CA tissues were statistically higher in $\mathrm{N}$ than analogous VA tissues (Fig. 4). VA leaves and seeds showed no difference in $\mathrm{N}$ content; however, CA seeds had significantly lower $\mathrm{N}$ than CA leaves. Phenolic concentration varied among the tissues in the experiment $(F=18.67, \mathrm{p}<0.0001)$. Among VA tissues, phenolic concentrations were highest in the seeds and flowering spathes, while in CA tissues phenolic concentra- tions were highest in vegetative leaves (Fig. 4). Tissues also varied in size, with vegetative shoots from VA considerably shorter $(F=242, \mathrm{p}<$ $0.0001)$ and leaves thinner $(F=80, \mathrm{p}<$ 0.0001 ) than those from CA. Likewise, flowering shoots from CA were much taller $(F=236, \mathrm{p}<0.0001)$ and spathes wider $(F=361, \mathrm{p}<0.0001)$. Further, seeds from VA were smaller in both length $(F=9.52, \mathrm{p}=0.009)$ and width $(F=40.9, \mathrm{p}<0.0001)$ (Fig. 5).

\section{DISCUSSION}

Very high abundances of the nonnative amphipod Ampithoe valida in San Francisco Bay coupled with the results of our feeding experiments demonstrate the potential for destructive rates of herbivory on eelgrass tissues in this system. Peak densities in this study were 1300 to 3200 ind. $\mathrm{m}^{-2}$, while a survey of amphipods, albeit using different sampling methods, in seagrasses from Massachusetts to Florida found 0 to 750 amphipods (of any species) $\mathrm{m}^{-2}$ (Nelson 1979). These animals are documented to consume epiphytes and macroalgae in their native habitats; however, in San Francisco Bay they also directly graze eelgrass, consuming vegetative tissue but preferring reproductive tissue including spathes and mature fruits or seeds. Consumption of sexual reproductive tissue has the potential to severely impact the stability of San Francisco Bay seagrass meadows, especially the large meadow at Crown Beach, a predominantly annual meadow that relies on seeds for interannual persistence.

Feeding experiment data often showed a preference for inflorescence tissue over vegetative tissue, and field data support these findings. A total of $85 \%$ of flowering shoots from the field survey showed herbivory damage, with $99 \%$ of spathes in later stages of development (those preferred in the feeding experiment) showing damage. In contrast, only $15 \%$ of vegetative shoots from the field survey showed damage consistent with amphipod herbivory. However, this could be an underestimate; amphipod herbivory on vegetative leaves appears as small crescent shaped areas removed (Fig. 6), but complete severing of the leaf is possible, leaving nothing that could be confidently scored as grazed. In contrast, amphi- 

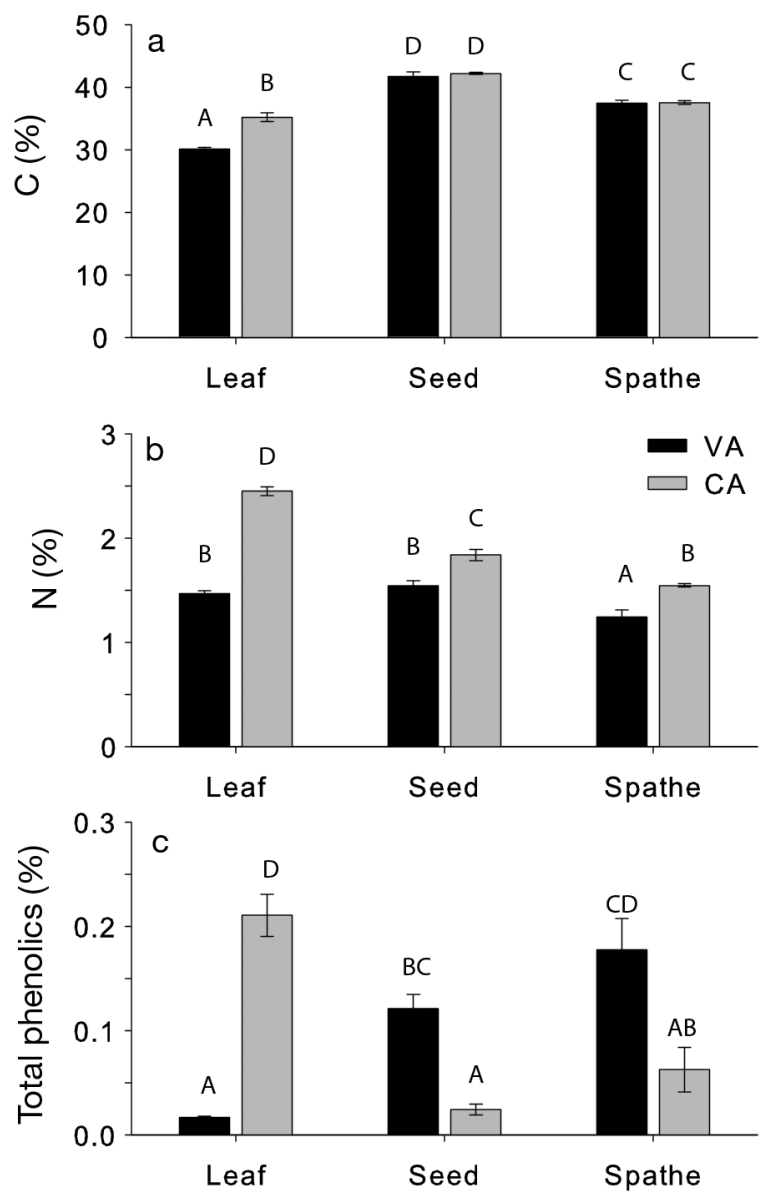

Fig. 4. Zostera marina. (a) Carbon, (b) nitrogen, and (c) total phenolic concentrations in tissues originating from Virginia (VA) and California (CA). Means \pm 1 SE. Different letters indicate significant differences according to post-hoc Tukey's tests

pod herbivory on spathes most often appears as removal of tissue around the developing fruits or consumption of fruits (Fig. 6), and probably was more accurately quantified.

Habitat complexity may contribute to the high rates of herbivory on flowering tissues. Field surveys showed that amphipods used flowering shoots as habitat more than they utilized vegetative shoots. Other species (but not all) have also shown a preference for flowering shoots over vegetative shoots (Hellwig-Armonies 1988, Nakaoka et al. 2008), perhaps due to greater complexity of inflorescence structures. More complex surfaces are often better habitat as they provide more niche space and greater refuge from predators (Klopfer \& Mac Arthur 1960, O'Connor 1991). Because amphipods use flowering shoots as habitat, they surely encounter them more often, which may contribute to the high rates of herbivory. It may also partly explain why we see higher
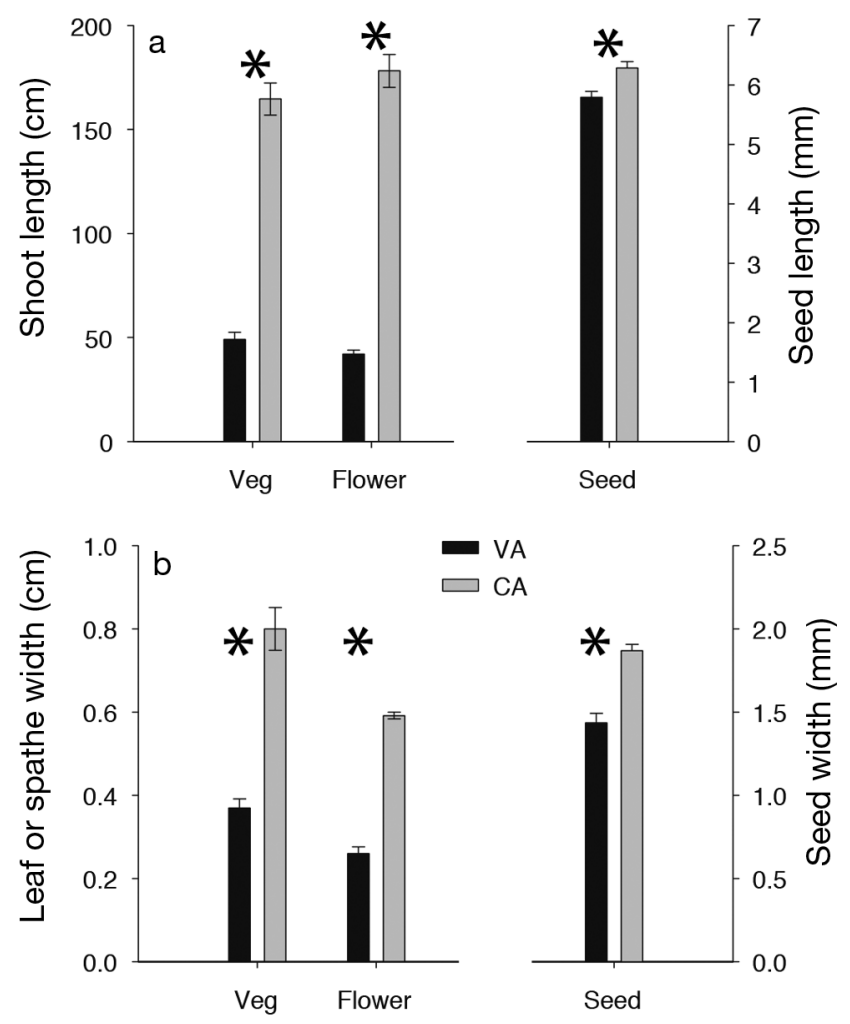

Fig. 5. Zostera marina. Lengths of vegetative leaves and flowering spathes (a), widths of vegetative leaves or spathes (b), and lengths and widths of seeds (right axis on both panels) originating from Virginia (VA) and California (CA) ( ${ }^{*}$ statistically different; $\left.\mathrm{p}<0.05\right)$. Means $\pm 1 \mathrm{SE}$

rates of herbivory on vegetative shoots in the microcosm feeding experiments than in the field. There were no predators in the experiments and amphipods may have spent less time seeking refuge in flowering shoots than they do in the field.

Herbivore food choices may also be driven by chemical cues or mechanical handling advantages, although we lack clear evidence that these factors were important in consumption patterns in the present study. Higher tissue N or lower C:N can promote herbivory (McGlathery 1995, Goecker et al. 2005); however, the late developmental stages of inflorescences, consumed at the highest rates, had lower nitrogen and higher carbon concentrations (thus higher $\mathrm{C}: \mathrm{N}$ ) than leaves or early-stage inflorescences. There is some evidence that Zostera marina can secrete phenolic compounds, which can act as a deterrent for epiphytic growth and invertebrate grazing and may be increased during times of intense grazing or disease infection (Harrison 1982, Vergeer \& Develi 1997). Amphipods are deterred by terpenoids produced by the brown alga Dictyota and 


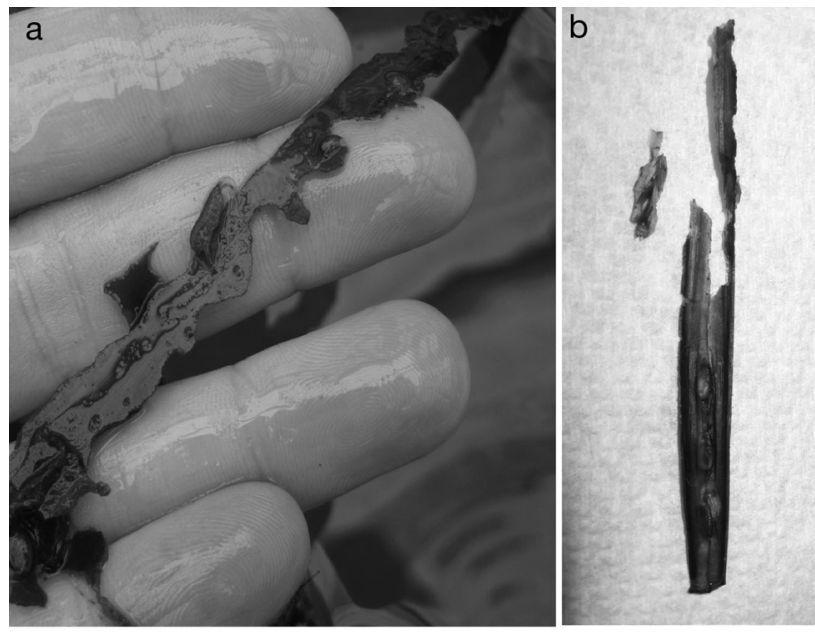

Fig. 6. Zostera marina (a) vegetative leaf and (b) flowering spathes damaged by the non-native amphipod Ampithoe valida

phenolics produced by the brown alga Fucus (Duffy \& Hay 1994, Kubanek et al. 2004). In the bicoastal experiment, we measured substantially greater total phenolics in CA leaves than CA stage 4 spathes or seeds; however, grazing patterns in that experiment overall do not correlate well with phenolic concentrations. Finally, amphipod herbivory on macroalgae can be affected by tissue toughness and manipulability (Taylor et al. 2002). While we did not measure these parameters, eelgrass vegetative leaves and flowering spathes are certainly different. We expect that spathes are tougher but that tissue hardness could increase handling ease (Taylor et al. 2002). These hypotheses could be explored in future work to better understand the frequent preference for flowering tissue.

Our calculations suggest that populations of these non-native amphipods at peak abundances can decimate the standing stock of seeds in $1 \mathrm{wk}$. Mature fruit or potential seed density at Crown Beach was $\sim 250$ seeds $\mathrm{m}^{-2}$. Feeding experiments showed that Ampithoe valida could consume mature fruits at a rate of 0.01 to 0.025 seeds ind. ${ }^{-1} \mathrm{~d}^{-1}$. With the measured A. valida density of 3200 ind. $\mathrm{m}^{-2}$, the population of amphipods is capable of consuming 32 to 80 seeds $\mathrm{m}^{-2} \mathrm{~d}^{-1}$ or all of the available seeds in $1 \mathrm{wk}$. From the lower density of A. valida measured in 2007 (1300 ind. $\mathrm{m}^{-2}$ ), the population is capable of consuming 13 to 33 seeds $\mathrm{m}^{-2} \mathrm{~d}^{-1}$ or all of the available seeds within 1 to $3 \mathrm{wk}$. These extrapolations might be an overestimate of percentage of seeds consumed, as the assessment of mature fruit or potential seed density was during a time of high amphipod herbivory; therefore, many fruits had already been consumed and were not accounted for. Zostera marina spathes are likely to have approximately 10 fruits as opposed to 5 (the number we counted in our surveys; authors' unpubl. data), doubling the density as well as the time required for amphipods to consume all of the seeds. Furthermore, amphipod herbivory rates were estimated in controlled conditions, where these animals likely spent more time eating than they would in the field where they would have to hide from predators. Despite the drawbacks of extrapolating controlled microcosm results, our field observations suggest that these rates are not unreasonable. In 2 eelgrass beds in San Francisco Bay (Crown Beach, toward the southern end of eelgrass distribution in the bay, and Point San Pablo, toward the northern end of the distribution along the north Richmond shoreline), mature fruits disappeared in $1 \mathrm{wk}$ on flowering shoots with abundant $A$. valida (along with signs of intense grazing consistent with our microcosm observations), making collection of seed for several restoration projects impossible (authors' pers. obs.).

In microcosm experiments, while amphipods tended to prefer flowering tissue, they also consumed large amounts of vegetative tissue. Peak productivity of vegetative shoots at Crown Beach is around $500 \mathrm{mg} \mathrm{m}^{-2} \mathrm{~d}^{-1}$ (Boyer unpubl. data). Amphipod herbivory rates on vegetative leaves $(0.07$ to $0.3 \mathrm{mg}$ ind. $^{-1} \mathrm{~d}^{-1}$ ) multiplied by maximum field densities (3200 ind. $\mathrm{m}^{-2}$ in 2006 and 1300 ind. $\mathrm{m}^{-2}$ in 2007) can remove 60 to $960 \mathrm{mg}$ vegetative tissue $\mathrm{m}^{-2} \mathrm{~d}^{-1}$. This results in consumption of an average of $75 \%$ of the daily production during the summer when amphipods are at greatest densities, with maximum consumption of $190 \%$ of total plant production $(12 \%$ at the lowest densities). This is well above the average of $<30 \%$ of seagrass production reaching higherorder consumers via direct grazing (Valentine \& Duffy 2006). While other studies have found larger proportions of total production consumed $(57 \%$ by fish and urchin) (Prado et al. 2007, 2008), these are the first estimates of such high herbivory rates by such a small mesograzer.

Herbivory on vegetative or flowering eelgrass tissue by Ampithoe valida in its native range has not been documented; in fact, a recent study in Chesapeake Bay found no evidence of A. valida consumption of eelgrass after evaluating feeding relationships with stable isotopes and gut content analyses (Douglass et al. 2011). In mesocosm studies with high epiphyte biomass and no invertebrate predators, Short et al. (1995) found that amphipod populations can 
bloom rapidly, deplete epiphyte standing stock, and consume eelgrass; however, they concluded that amphipod damage in nature is limited to leaf edges when there are other food options and predators to keep the population in check. In San Francisco Bay, different predator species and perhaps lower predation rates than found in A. valida's native range may foster high amphipod abundances (Carr 2008, L. Carr $\&$ K. Boyer unpubl. data). Peak epiphyte loads tend to be much lower in San Francisco Bay eelgrass beds (0.1 to $9 \mathrm{~g} \mathrm{~m}^{-2}$; G. Santos \& K. Boyer unpubl. data) than in other published studies from the eastern US, where these amphipods are native (2 to $2306 \mathrm{~g} \mathrm{~m}^{-2}$; Penhale 1977, Short et al. 1995, Moore \& Wetzel 2000), and macroalgal abundances (G. Santos \& K. Boyer unpubl. data) in San Francisco Bay eelgrass beds are also relatively low. The fact that eelgrass tissues were readily consumed in our experiments even when the most common green (Ulva) and red (Gracilaria) species and epiphytic algae were offered suggests that this amphipod has a broader diet than in its native range, which may be reinforced by natural selection over time if algal choices are indeed limited.

Differences in environmental conditions do not completely explain the discrepancy of high eelgrass herbivory rates in the invaded meadows of San Francisco Bay and lack of eelgrass herbivory in native habitats. The non-native amphipods preferred tissue from San Francisco Bay over tissue from their native habitat of Virginia when presented in the same environment. It is possible but unlikely that transport changed the Virginia plants to make them less palatable. While the nitrogen content of CA plants was higher than that of VA plants, perhaps increasing palatability, nitrogen alone cannot explain food preference. The VA stage 4 spathes had lower nitrogen and higher carbon content than VA leaves, but were consumed at significantly lower rates. Further, high $\mathrm{N}$ content of CA leaves compared to CA spathes did not lead to greater leaf consumption.

Eelgrass in our bi-coastal feeding experiment had moderate levels of phenolic compounds, but these also do not adequately explain the preference for CA tissue. Despite significantly higher phenolic concentrations in CA vegetative tissue, it was consumed at higher rates than that from VA. It is curious that the patterns of phenolic concentrations were different in $\mathrm{CA}$ and VA tissues, with VA plants seemingly protecting sexual reproductive tissue with chemical defenses and CA plants protecting vegetative tissue, perhaps pointing to a difference in selective pressures in the two habitats.
Discrepancies between apparent palatability and food preferences are not unusual. Sea urchins, while consuming large amounts of vegetative tissue, preferred inflorescences of Posidonia oceanica, even though they had low nitrogen and high phenolic concentrations because the vegetative leaves of $P$. oceanica are structurally defended (Vergés et al. 2007). The amphipod Ampithoe longimana feeds on macroalgae that are less palatable because they provide better habitat (Duffy \& Hay 1994). Likewise, CA plants may act as a better habitat than VA plants. CA plants are larger (Fig. 5) and may provide more protection from predators for the amphipod, which had an initial length of $8.3 \mathrm{~mm} \pm 0.3$ (mean $\pm \mathrm{SE}$ ) in the bicoastal experiment. Habitat preference may allow for more interactions with CA tissue and thus higher feeding rates. While we would expect such an effect to be largely limited to complex inflorescence tissues, structurally simple leaf tissue from CA was also consumed at much greater rates than VA leaves despite controlling for relative apparency.

Herbivory on both flowering shoots and vegetative leaves at the rates measured could have important ecological impacts, influencing both structural and functional properties of the seagrass community. Removing a large portion of the seeds from a seagrass meadow will decrease successful sexual reproduction. Meadows may be maintained through clonal expansion, but over time genetic diversity will be depressed, which can reduce population growth, individual fitness, and possibly long-term persistence (Williams 2001), and genetic variation can also increase resistance to disturbance or stress (Hughes \& Stachowicz 2004, Reusch et al. 2005). Low salinity events, oil spills, and high turbidity events are regular stressors in San Francisco Bay. While amphipod densities vary annually (Fig. 1), if a large disturbance occurs during a high amphipod abundance year, reduced seed availability could hinder recovery. This has implications for conservation efforts, as seagrasses are highly valued for ecosystem services such as habitat provision, nutrient cycling, and sediment stabilization (Costanza et al. 1997, Waycott et al. 2009). Years of low seed production may be particularly important to meadows that exhibit an annual life cycle such as the one at Crown Beach, relying on seedling recruitment for population persistence from year to year.

Along with several other recent studies (Nakaoka 2002, Heck \& Valentine 2006), ours challenges the paradigm that invertebrate herbivory in seagrass systems is limited to epiphytes and thus results in positive influences on the seagrass itself. The present 
study shows a large effect of herbivory by amphipods on a seagrass in a temperate environment, where direct consumption of the plants is thought to be especially low (Heck \& Valentine 2006). We document a highly adaptable mesograzer species that apparently has altered its diet to both include and heavily impact eelgrass when introduced into a new environment. We recommend vigilance in programs to control non-native species introductions in other estuaries, as well as efforts to maintain and enhance predatory fish populations that could help to keep invertebrate consumers in check.

Acknowledgements. This work was conducted with permission and permits from East Bay Regional Park District and the California Department of Fish and Game. Support was provided by the NOAA Restoration Center and California State Coastal Conservancy. We thank Diana Singh, Ace Crow, Adam Damon, and Gwen Santos for assistance with field surveys and experiments.

\section{LITERATURE CITED}

Armitage AR, Fourqurean JW (2006) The short-term influence of herbivory near patch reefs varies between seagrass species. J Exp Mar Biol 339:65-74

Bolser RC, Hay ME, Lindquist N, Fenical W, Wilson D (1998) Chemical defenses of freshwater macrophytes against crayfish herbivory. J Chem Ecol 24:1639-1658

Bousfield EL (1973) Shallow-water Gammaridean Amphipoda of New England. Comstock Pub Associates, Ithaca, NY

- Brearley A, Walker DI (1995) Isopod miners in the leaves of two Western Australian Posidonia species. Aquat Bot 52: 163-181

> Carlsson NOL, Brönmark C, Hansson L (2004) Invading herbivory: the golden apple snail alters ecosystem functioning in Asian wetlands. Ecology 85:1575-1580

Carr LA (2008) Epifaunal community structure and trophic interactions in eelgrass (Zostera marina) habitats of San Francisco Bay. MS thesis, San Francisco State University, San Francisco, CA

Carr LA, Boyer KE, Brooks AJ (2011) Spatial patterns of epifaunal communities in San Francisco Bay eelgrass (Zostera marina) beds. Mar Ecol (Berl) 32:88-103

Cohen AN, Carlton JT (1995) Nonindigenous aquatic species in a United States estuary: a case study of the biological invasions of the San Francisco Bay and Delta. In: Report for USFWS, WA, DC, and Connecticut Sea Grant

Costanza R, D'Arge R, De Groot R, Farber S and others (1997) The value of the world's ecosystem services and natural capital. Nature 387:253-260

De Cock AWAM (1980) Flowering, pollination and fruiting in Zostera marina L. Aquat Bot 9:201-220

Donlan CJ, Tershy BR, Croll DA (2002) Islands and introduced herbivores: conservation action as ecosystem experimentation. J Appl Ecol 39:235-246

Douglass JG, Duffy JE, Canuel EA (2011) Food web structure in a Chesapeake Bay eelgrass bed as determined through gut contents and ${ }^{13} \mathrm{C}$ and ${ }^{15} \mathrm{~N}$ isotope analysis. Est Coasts 34:701-711
Duffy JE, Hay ME (1994) Herbivore resistance to seaweed chemical defense: the roles of mobility and predation risk. Ecology 75:1304-1319

Edmunds PJ, Carpenter RC (2001) Recovery of Diadema antillarum reduces macroalgal cover and increases abundance of juvenile corals on a Caribbean reef. Proc Natl Acad Sci USA 98:5067-5071

Estes JA, Duggins DO (1995) Sea otters and kelp forests in Alaska: generality and variation in a community ecological paradigm. Ecol Monogr 65:75-100

Fine PVA, Mesones I, Coley PD (2004) Herbivores promote habitat specialization by trees in Amazonian forests. Science 305:663-665

Fishman JR, Orth RJ (1996) Effects of predation on Zostera marina L. seed abundance. J Exp Mar Biol 198:11-26

Fritz RS, Simms EL (1992) Plant resistance to herbivores and pathogens: ecology, evolution, and genetics. University of Chicago Press, Chicago, IL

Goecker ME, Heck KL, Valentine JF (2005) Effects of nitrogen concentrations in turtlegrass Thalassia testudinum on consumption by the bucktooth parrotfish Sparisoma radians. Mar Ecol Prog Ser 286:239-248

Green EP, Short FT (2003) World atlas of seagrasses. University of California Press, Berkeley, CA

> Hämmerli A, Reusch TBH (2003) Inbreeding depression influences genet size distribution in a marine angiosperm. Mol Ecol 12:619-629

> Harrison PG (1982) Control of microbial growth and of amphipod grazing by water-soluble compounds from leaves of Zostera marina. Mar Biol 67:225-230

Heck KL, Valentine JF (2006) Plant-herbivore interactions in seagrass meadows. J Exp Mar Biol 330:420-436

Hellwig-Armonies M (1988) Mobile epifauna on Zostera marina, and infauna of its inflorescences. Helgol Mar Res 42:329-336

Hemminga M, Duarte C (2000) Seagrass ecology. Cambridge University Press, Cambridge

> Holbrook SJ, Reed DC, Hansen K, Blanchette CA (2000) Spatial and temporal patterns of predation on seeds of the surfgrass Phyllospadix torreyi. Mar Biol 136: 739-747

> Hughes AR, Stachowicz J (2004) Genetic diversity enhances the resistance of a seagrass ecosystem disturbance. Proc Natl Acad Sci USA 101:8998-9002

> Hughes AR, Bando K, Rodriguez LF, Williams SL (2004) Relative effects of grazers and nutrients on seagrasses: a meta-analysis approach. Mar Ecol Prog Ser 282:87-99

Jackson JBC, Kirby MX, Berger SH, Bjorndal KA and others (2001) Historical overfishing and the recent collapse of coastal ecosystems. Science 293:629-637

Klopfer PH, Mac Arthur R (1960) Niche size and faunal diversity. Am Nat 94:293-300

> Leavitt H, Robertson IC (2006) Petal herbivory by chrysomelid beetles (Phyllotreta sp.) is detrimental to pollination and seed production in Lepidium papilliferum (Brassicaceae). Ecol Entomol 31:657-660

Lehtilä K, Strauss SY (1997) Leaf damage by herbivores affects attractiveness to pollinators in wild radish, Raphanus raphanistrum. Oecologia 111:396-403

> Lockwood JR III (1998) On the statistical analysis of multiple-choice feeding preference experiments. Oecologia 116:475-481

Lubchenco J, Gaines SD (1981) A unified approach to marine plant-herbivore interactions. I. Populations and Communities. Annu Rev Ecol Syst 12:405-437 
Kubanek J, Lester SE, Fenical W, Hay ME (2004) Ambiguous role of phlorotannins as chemical defenses in the brown alga Fucus vesiculosus. Mar Ecol Prog Ser 277:79-93

Manly BFJ (1993) Comments on design and analysis of multiple-choice feeding-preference experiments. Oecologia 93:149-152

McGlathery KJ (1995) Nutrient and grazing influences on a subtropical seagrass community. Mar Ecol Prog Ser 122: 239-252

> Moore KL, Wetzel RL (2000) Seasonal variations in eelgrass (Zostera marina L.) responses to nutrient enrichment and reduced light availability in experimental ecosystems. J Exp Mar Biol Ecol 244:1-28

Mumby PJ, Dahlgren CP, Harborne AR, Kappel CV and others (2006) Fishing, trophic cascades, and the process of grazing on coral reefs. Science 311:98-101

Mutikainen P, Delph LF (1996) Effects of herbivory on male reproductive success in plants. Oikos 75:353-358

Nakaoka M (2002) Predation on seeds of seagrasses Zostera marina and Zostera caulescens by a tanaid crustacean Zeuxo sp. Aquat Bot 72:99-106

> Nakaoka M, Matsumasa M, Toyohara T, Williams SL (2008) Animals on marine flowers: does the presence of flowering shoots affect mobile epifaunal assemblage in an eelgrass meadow? Mar Biol 153:589-598

Nelson WG (1979) An analysis of structural pattern in an eelgrass (Zostera marina L.) amphipod community. J Exp Mar Biol 39:231-264

Nicotri ME (1980) Factors involved in herbivore food preference. J Exp Mar Biol 42:13-26

Nienhuis PH, Groenendijk AM (1986) Consumption of eelgrass (Zostera marina) by birds and invertebrates: an annual budget. Mar Ecol Prog Ser 29:29-35

O'Connor NA (1991) The effects of habitat complexity on the macroinvertebrates colonizing wood substrates in a lowland stream. Oceologia 85:504-512

Orth RJ, Kendrick GA, Marion SA (2002) Posidonia australis seed predation in seagrass habitats of Two Peoples Bay, Western Australia. Aquat Bot 86:83-85

Orth RJ, Carruthers T, Dennison WC, Duarte CM and others (2006) A global crisis for seagrass ecosystems. Bioscience 56:987-996

Penhale PA (1977) Macrophyte-epiphyte biomass and productivity in an eelgrass (Zostera marina L.) community. J Exp Mar Biol Ecol 26:211-224

> Peterken CJ, Conacher CA (1997) Seed germination and recolonisation of Zostera capricorni after grazing by dugongs. Aquat Bot 59:333-340

Prado P, Tomas F, Alcoverro T, Romero J (2007) Extensive direct measurements of Posidonia oceanica defoliation confirm the importance of herbivory in temperate seagrass meadows. Mar Ecol Prog Ser 340:63-71

Prado P, Farina S, Tomas F, Romero J, Alcoverro T (2008) Marine protection and meadow size alter fish herbivory in seagrass ecosystems. Mar Ecol Prog Ser 371:11-21

Reusch T, Ehlers A, Hämmerli A, Worm B (2005) Ecosystem recovery after climatic extremes enhanced by genotypic

Editorial responsibility: Kenneth Heck Jr., Dauphin Island, Alabama, USA diversity. Proc Natl Acad Sci USA 102:2826-2831

Roa R (1992) Design and analysis of multiple-choice feeding-preference experiments. Oecologia 89:509-515

Schmitz OJ (2008) Herbivory from individuals to ecosystems. Annu Rev Ecol Evol Syst 39:133-152

Short FT, Wyllie-Echeverria S (1996) Natural and humaninduced disturbance of seagrasses. Environ Conserv 23: $17-27$

> Short FT, Burdick DM, Kaldy JE (1995) Mesocosm experiments quantify the effects of eutrophication on eelgrass, Zostera marina. Limnol Oceanogr 40:740-749

> Short FT, Polidoro P, Livingstone SR, Carpenter KE and others (2011) Extinction risk assessment of the world's seagrass species. Biol Conserv 144:1961-1971

Taylor RB, Sotka E, Hay ME (2002) Tissue-specific induction of herbivore resistance: seaweed response to amphipod grazing. Oecologia 132:68-76

Valentine JF, Duffy JE (2006) The central role of grazing in seagrass ecology. In: Larkum AWD, Orth RJ, Duarte CM (eds) Seagrasses: biology, ecology, and conservation. Springer, Dordrecht

Valentine JF, Heck KL (1999) Seagrass herbivory: evidence for the continued grazing of marine grasses. Mar Ecol Prog Ser 176:291-302

> Valentine JF, Heck KL, Busby J, Webb D (1997) Experimental evidence that herbivory can increase shoot density in a subtropical turtlegrass (Thalassia testudinum) meadow. Oecologia 112:193-200

Vergeer LH, Develi A (1997) Phenolic acids in healthy and infected leaves of Zostera marina and their growthlimiting properties towards Labyrinthula zosterae. Aquat Bot 58:65-72

- Vergés A, Becerro MA, Alcoverro T, Romero J (2007) Variation in multiple traits of vegetative and reproductive seagrass tissues influences plant-herbivore interactions. Oecologia 151:675-686

Wardle DA, Barker GM, Yeates GW, Bonner KI, Ghani A (2001) Introduced browsing mammals in New Zealand natural forests: aboveground and belowground consequences. Ecol Monogr 71:587-614

Waycott M, Duarte CM, Carruthers TJB, Orth RJ and others (2009) Accelerating loss of seagrasses across the globe threatens coastal ecosystems. Proc Natl Acad Sci USA 106:12377-12381

> Wigand C, Churchill AC (1988) Laboratory studies on eelgrass seed and seedling predation. Est Coasts 11:180-183

Williams SL (2001) Reduced genetic diversity in eelgrass transplantations affects both individual and population fitness. Ecol Appl 11:1472-1488

Zieman JC, Iverson RL, Ogden JC (1984) Herbivory effects on Thalassia testudinum leaf growth and nitrogen content. Mar Ecol Prog Ser 15:151-158

Zimmerman RC, Kohrs DG, Alberte RS (1996) Top-down impact through a bottom-up mechanism: the effect of limpet grazing on growth, productivity and carbon allocation of Zostera marina L. (eelgrass). Oecologia 107: $560-567$

Submitted: February 18, 2011; Accepted: December 19, 2011 Proofs received from author(s): March 28, 2012 